\title{
Detection of Altered Risk Factors in Hospitalized Patients with Coronary Artery Disease
}

\author{
Avany Fernandes Pereira, Maria Dorotéia Borges dos Santos, Antônio Carlos Cicogna, \\ Carlos Roberto Padovani, Eliane de Abreu Soares, Roberto Carlos Burini \\ Botucatu, SP - Brazil
}

\begin{abstract}
Objective - To assess biochemical, anthropometric, and dietary variables considered risk factors for coronary arterydisease.

Methods - Using anthropometrics, dietary allowance, and blood biochemistry, we assessed 84 patients [54 males (mean age of $55 \pm 8$ years) and 30 females (mean age of $57 \pm 7$ years)], who had severe ( $\geq 70 \%$ coronary artery obstruction) and nonsevere forms of coronary artery disease determined by cardiac catheterization. The severe form of the disease prevailed in $70 \%$ of the males and $64 \%$ of the females, and a high frequency offamilial antecedents $(92 \%$ ' $88 \%)$ and history of acute myocardial infarction (80\%' $70 \%)$ were observed. Smoking predominated among males (65\%) and diabetes mellitus among females (43\%).
\end{abstract}

Results - Males and females had body mass index and body fat above the normal values. Females with nonsevere lesions had HDL $>35 \mathrm{mg} / \mathrm{dL}$, and this constituted a discriminating intergroup indicator. Regardless of the severity of the disease, hyperglycemia and hypertriglyceridemia were found among females, and cholesterolemia $>200 \mathrm{mg} /$ $d L$ in both sexes, but only males had LDL fraction $>160$ $\mathrm{mg} / \mathrm{dL}$ and homocysteine $>11.7 \mathrm{mmol} / \mathrm{L}$. The male dietary allowance was inadequate in nutrients for homocysteine metabolism and in nutrients with an antioxidant action, such as the vitamins $B_{6}, C$, and folate. Individuals of both sexes had a higher lipid and cholesterol intake and an inadequate consumption of fiber. The diet was classified as high-protein, high-fat, and low-carbohydrate.

Conclusion - The alterations found had no association with the severity of lesions, indicating the need for more effective nutritional intervention.

Key words: risk factors, individuals with coronary artery disease, hospitalization

Faculdade de Medicina de Botucatu - UNESP

Mailing address: Avany Fernandes Pereira - Rua Armando de Barros, 397/304 18600-050 - Botucatu, SP, Brazil - E-mail: anyfer@fmb.unesp.br

English version by Stela Maris C. e Gandour
In the past few years, a marked reduction in mortality due to cardiovascular diseases has occurred, even though those diseases remain the major cause of mortality worldwide according to the American Heart Association ${ }^{1}$.

The multifactorial etiology of coronary artery disease reveals the existence of several risk indicators, many of which may be modified by effective interventions ${ }^{2}$. On the other hand, some studies show that the risk factors, when kept active, contribute to the progression of coronary lesions, worsening the patient's prognosis ${ }^{3}$

According to dietary recommendations for preventing coronary artery disease, the factors related to its development or worsening, or both, are the following: total fat intake above $30 \%$ and saturated fatty acid intake above $10 \%$ of the total caloric value of the diet; dietary cholesterol above $300 \mathrm{mg} /$ day; inadequate intake of vitamins and antioxidant minerals and of vitamins involved in the metabolism of methionine; dietary fiber below $20 \mathrm{~g} /$ day; sodium consumption above $6 \mathrm{~g} /$ day; and high-caloric diets ${ }^{4-7}$.

The current study assessed the levels of factors associated with coronary artery disease in patients hospitalized due to coronary artery disease, aiming at checking whether the severity of the coronary artery lesion was related to the alterations in risk factors.

\section{Methods}

We carried out a cross-sectional observational study with 84 patients hospitalized for the treatment of coronary artery disease in a ward of a public general hospital affiliated with the School of Medicine of Botucatu in the Central-Western region of the State of São Paulo, from March to August 1998. The inclusion criterion was the diagnosis of coronary artery disease through clinical examination and cardiac catheterization. The exclusion criteria were as follows: hospitalization time insufficient for data collection, presence of severe cardiac disease making the patient's assessment impossible, recent acute myocardial infarction (time $\leq 3$ months in regard to the period studied), and presence of other chronic diseases, such 
as decompensated diabetes mellitus, renal, respiratory, or hepatic insufficiency, and cancer.

The individuals were divided into 4 groups according to sex and the severity of the coronary artery lesion using the criterion of the Sociedade de Cardiologia do Estado de São Paulo ${ }^{8}$, which considers coronary artery obstruction $\geq$ $70 \%$ as a severe lesion. The groups were as follows: groups 1 and 2 (G1 and G2) comprised 57 (38 males and 19 females) patients with severe coronary lesions; groups 3 and 4 (G3 and G4) comprised 27 ( 16 males and 11 females) patients with nonsevere coronary artery lesions.

This study was approved by the Committee on Ethics and Research in Human Beings of the School of Medicine of Botucatu.

A personal questionnaire was used to characterize the patients studied with information on sex, age, marital status, smoking status, occurrence of acute myocardial infarction, systemic hypertension, diabetes mellitus, angina pectoris, and hospitalization duration. The severity of the coronary artery disease was established with the analysis of the cardiac catheterization and after clinical examination.

The anthropometric examination comprised the following measurements: weight; height; triceps, biceps, subscapular, and supra-iliac skinfolds (using the Lange ${ }^{\circledR}$ caliper, USA); arm, waist, and hip circumferences (using the millimetric nonextendable tape); and subsequent calculation of the muscle circumference of the arm, waist/hip ratio, and body mass index ${ }^{9-11}$. The sum of the skinfold values was determined and the Durnin and Wormesley method was applied ${ }^{12}$.

The following reference values were used: the World Health Organization (WHO) standard ${ }^{13}$ for body mass index, the Frisancho ${ }^{14}$ standard for the arm circumference and the muscle circumference of the arm, and the Bray standard ${ }^{15}$ for the waist/hip ratio. The normal ranges for body fat were $15-18 \%$ for males and $20-25 \%$ for females ${ }^{16}$.

The dietary inquiry was applied on the $1^{\text {st }}$ day of hospitalization using a 24-hour recall. To increase the reliability of the measuring spoon measurements reported by the interviewees, the manual of photographic record for dietary inquiries was used as support material ${ }^{17}$. In addition to the structured 24-hour recall, we used a questionnaire about the preferred way of preparing food, appetite, allergies, food aversions and preferences, number of meals/day, and use of vitamin and mineral supplements.

To analyze the quantitative data of food intake, measuring spoon measurements of food and beverages reported by the interviewees were converted into grams according to Soares et al ${ }^{18}$ and Pinheiro et al ${ }^{19}$.

The intake of energy, proteins, lipids, carbohydrates, unsaturated lipids, dietary cholesterol, vitamins $\mathrm{C}$ and $\mathrm{E}$, folic acid, vitamins $\mathrm{B}_{6}$ and $\mathrm{B}_{12}$, and dietary fiber was calculated with the aid of Virtual Nutry software ${ }^{20}$.

The values obtained were then compared with the dietary aliquots recommended by the National Research Council/Recommended Dietary Allowances (NRC/RDA-1989) ${ }^{21}$. In regard to adequacy, the individuals were grouped into the 3 following consumption ranges: $<67 \%$ of adequacy (inadequate), from $67 \%$ to $100 \%$ (borderline), and $\geq 100 \%$ of adequacy (adequate). The World Health Organization standards were adopted for daily dietary fiber intake ${ }^{7}$. Lipid consumption was compared with the values recommended by the National Cholesterol Education Program ${ }^{5}$ for the percent dietary fat in relation to the total energy value, dietary cholesterol, and unsaturated lipids.

The biochemical analyses performed in venous blood samples were obtained after nocturnal fasting ranging from 8 to 12 hours, through venous puncture with a closed vacuum system (Vacutainer ${ }^{\circledR}$ - England). The samples were then centrifuged for 10 minutes $(3000 \mathrm{rpm})$ and the decanted plasma was analyzed with an automatic analyzer (model RAXT OU Ra 1000 - Technicon ${ }^{\circledR}$ - USA). The following plasma measurements were performed: glucose, total cholesterol, HDL-cholesterol, triglycerides, and total homocysteine, the latter with a high-performance liquid chromatographic assay ${ }^{22}$.

LDL-cholesterol was calculated with the Friedewald formula ${ }^{23}$ and the total cholesterol/HDL-cholesterol ratio, and the values were compared with the normal values by Castelli et al ${ }^{24}$.

The lipid levels were compared with those recommended by the $2^{\circ}$ Consenso Brasileiro sobre Dislipidemias ${ }^{25}\left(2^{\text {nd }}\right.$ Brazilian Consensus on Dyslipidemias). The normal glycemia range was established from 70 to $110 \mathrm{mg} / \mathrm{dL}$ according to the criteria of the American Diabetes Association ${ }^{26}$.

The reference values used for homocysteine ranged from 4.90 to $11.70 \mu \mathrm{mol} / \mathrm{L}$ according to Ubbink et al ${ }^{24}$.

The statistical analysis was performed with the analysis of variance (ANOVA) for the values of score-z and median, applying the study of comparison between the groups through the nonparametric analog of analysis of variance (Kruskal-Wallis test) complemented by its respective test of multiple comparisons ${ }^{27}$.

The results were discussed based on the significance level of $5 \%(\mathrm{p}<0.005)$.

\section{Results}

Analyzing the characteristics of the sample, we observed that most patients were males (64\%), acute myocardial infarction predominated in approximately $80 \%$ of the males and in $70 \%$ of the females, the mean age was similar for males and females ( $55 \pm 8$ and $57 \pm 7$ years, respectively), a positive familial history of coronary artery disease predominated in both sexes, and tobacco use was more prevalent among males $(42 \%)$.

Other diseases, such as arterial hypertension and angina pectoris, were also observed in males and females. Severe coronary artery lesions were extremely prevalent and detected in $70 \%$ of the males and in $64 \%$ of the females (tab. I).

Of the anthropometric values, the percent body fat of males was above $18 \%$ and of females above $25 \%$. In regard to the distribution of body fat, the waist/hip ratio was greater in the 2 male groups (G1 and G3) as compared with the female group with nonsevere lesions (tab. II).

The median values of body mass index did not statistically differ among the groups studied, and individuals of 


\begin{tabular}{|lcc|}
\hline \multicolumn{3}{|c|}{ Table I - Characterization of the sample according to sex } \\
\hline Characteristics & $\begin{array}{c}\text { Males } \\
(\mathrm{n}=54)\end{array}$ & $\begin{array}{c}\text { Females } \\
(\mathrm{n}=30)\end{array}$ \\
\hline & $10 \pm 2$ & $12 \pm 3$ \\
Hospitalization (days) $*$ & $55 \pm 8$ & $57 \pm 7$ \\
Age (years) $*$ & - & $80 \%(24)$ \\
Menopause $* *$ & $65 \%(35)$ & $54 \%(16)$ \\
Smoking ** & $20 \pm 8$ & $15 \pm 5$ \\
Cigarettes/day $*$ & $92 \%(50)$ & $88 \%(27)$ \\
Positive familial history $* *$ & $70 \%(38)$ & $64 \%(20)$ \\
Severe coronary artery lesion** & $50 \%(27)$ & $60 \%(18)$ \\
Angina pectoris** & $18 \%(10)$ & $43 \%(13)$ \\
Diabetes mellitus ** & $50 \%(27)$ & $60 \%(18)$ \\
Arterial hypertension $* *$ & $80 \%(43)$ & $70 \%(20)$ \\
Acute myocardial infarction $* *$ & \\
\hline * Mean and standard deviation; $* *$ & percentage and number of individuals. \\
\hline
\end{tabular}

both sexes were classified as preobese according to the Reports of $\mathrm{WHO}^{28}$ (tab. II).

In regard to biochemical values, homocysteinemia was greater in the male sex, regardless of the severity of the coronary artery disease (tab. II).

Of the remaining plasma parameters analyzed, only triglycerides showed a statistical difference in the groups; lower values were found in the male groups (G1 and G3) than those found in females with severe coronary artery lesion(G2)(tab.II).

The HDL-cholesterol and LDL-cholesterol values were similar in both groups. Total cholesterol levels were above the recommended values in all groups, and they showed no significant differences according to the severity of the disease (tab. II).

The total cholesterol/HDL-cholesterol ratios showed significant difference with sexes, and both groups had increased values, which was compatible with an increased risk for coronary artery disease (tab. II). This ratio was higher in males with severe coronary artery lesions, showing a significant correlation with the type of lesion in the male sex (tab. II). Both G3 and G2 had glycemia results above those recommended with no relation to the severity of the lesions (tab. II).

In regard to diet, the percentage contribution of macronutrients characterized the diet as high-fat, high-protein, and low-carbohydrate for both sexes (fig. 1). Analyzing the amount of protein consumed according to body weight, the diet was considered high-protein with protein consumption above $1 \mathrm{~g} / \mathrm{kg} /$ day for all groups studied. The assessment of dietary quantitative consumption revealed an increased ingestion of total lipids in both sexes. The excessive ingestion of dietary cholesterol was also significantly higher in males as compared with that in females in all groups. On the other hand, an insufficient ingestion of unsaturated lipids was observed in both sexes, and it was more significant in males than in females (tab. III). The consumption of dietary fiber was lower than that recommended, with no statistical differentiation between the groups studied (tab. III). In addition, only $13 \%$ of the males and $6 \%$ of the females reached the adequate level of at least $30 \mathrm{~g} /$ day proposed by $\mathrm{WHO}^{7}$.

In regard to dietary vitamin intake, the median intake observed in isolation showed no dietary inadequacy. However, when the percentage of individuals with adequate consumption according to RDA ${ }^{21}$ was analyzed, the results showed that of the vitamins with antioxidant potential, vitamin $\mathrm{C}$ was consumed more by the female groups, regardless of the severity of the coronary lesions (tab. III). This resulted in a significantly greater adequacy in the female groups as compared with that in the male groups. Vitamin E showed a better percentage of adequacy, and all females and almost all males had an adequate consumption of that vitamin (tab. III). Vitamin B6 was adequately consumed in 50\% and $48 \%$ of the male groups 1 and 3 , and in $60 \%$ and $62 \%$ of the female groups 2 and 4; therefore, no difference was observed among the groups. Vitamin B12 showed good levels of ade-

\begin{tabular}{|c|c|c|c|c|c|}
\hline Variables & Group $1(\mathrm{n}=38)$ & Group $2(\mathrm{n}=19)$ & Group $3(n=16)$ & Group $4(\mathrm{n}=11)$ & Result of the test * \\
\hline BMI $\left(\mathrm{kg} / \mathrm{m}^{2}\right)$ & $28 \pm 5$ & $27 \pm 6$ & $26 \pm 4$ & $28 \pm 6$ & $\begin{array}{l}6.30 \\
(\mathrm{p}>0.05)\end{array}$ \\
\hline Percent body fat (\%) & $25 \pm 6^{\mathrm{a}}$ & $32 \pm 6^{\mathrm{b}}$ & $25 \pm 4^{\mathrm{a}}$ & $32 \pm 6^{b}$ & $\begin{array}{l}23.44 \\
(\mathrm{p}<0.01) \dagger\end{array}$ \\
\hline Waist/hip ratio & $0.99 \pm 0.05^{\mathrm{a}}$ & $0.94 \pm 0.09^{\mathrm{b}}$ & $0.98 \pm 0.05^{\mathrm{a}}$ & $0.92 \pm 0.06^{b}$ & $\begin{array}{l}10.76 \\
(\mathrm{p}<0.05) \dagger\end{array}$ \\
\hline Total cholesterol (mg\%) & $224 \pm 45$ & $226 \pm 47$ & $222 \pm 40$ & $220 \pm 39$ & $\begin{array}{l}1.11 \\
(\mathrm{p}>0.05)\end{array}$ \\
\hline HDL-cholesterol (mg\%) & $30 \pm 14$ & $34 \pm 12$ & $31 \pm 11$ & $38 \pm 13$ & $\begin{array}{l}1.57 \\
(\mathrm{p}>0.05)\end{array}$ \\
\hline LDL-cholesterol (mg\%) & $155 \pm 37$ & $164 \pm 43$ & $158 \pm 35$ & $163 \pm 41$ & $\begin{array}{l}1.17 \\
(p>0.05)\end{array}$ \\
\hline $\mathrm{TC} / \mathrm{HDL}$ & $11 \pm 3^{\mathrm{a}}$ & $9 \pm 2^{\mathrm{b}}$ & $7 \pm 4^{\mathrm{b}}$ & $8 \pm 3^{b}$ & $\begin{array}{l}20.30 \\
(p>0.01) \dagger\end{array}$ \\
\hline Glycemia (mg) & $106 \pm 20^{\mathrm{a}}$ & $132 \pm 41^{b}$ & $118 \pm 21^{\mathrm{a}}$ & $128 \pm 40^{\mathrm{ab}}$ & $\begin{array}{l}10.67 \\
(\mathrm{p}<0.05) \dagger\end{array}$ \\
\hline Homocysteine $(\mu \mathrm{mol} / \mathrm{l})$ & $8.10 \pm 3.57^{\mathrm{a}}$ & $6.00 \pm 1.24^{\mathrm{b}}$ & $8.93 \pm 3.32^{\mathrm{a}}$ & $5.75 \pm 1.08^{b}$ & $\begin{array}{l}17.13 \\
(\mathrm{p}<0.05) \dagger\end{array}$ \\
\hline
\end{tabular}




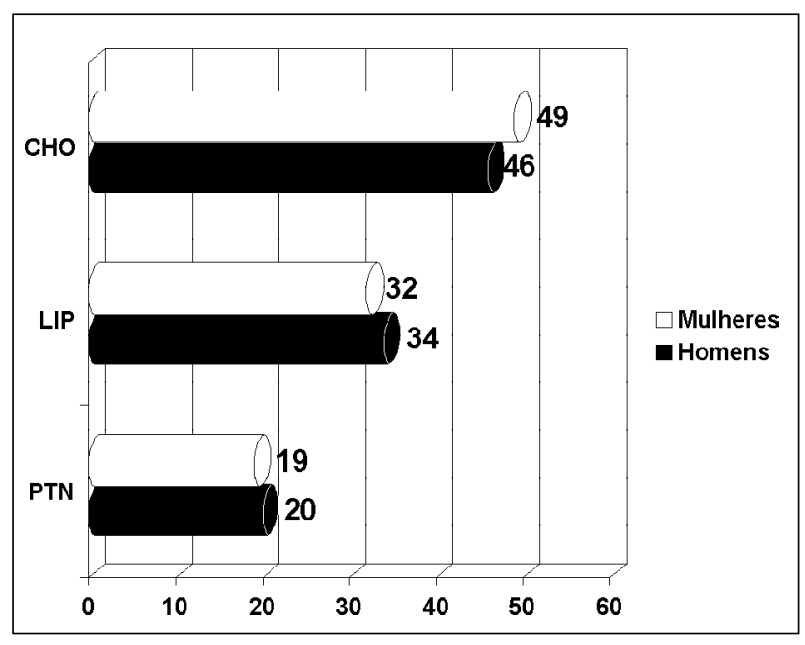

Fig. 1 - The percentage contribution of macronutrients in relation to daily total energy intake according to sex.

quacy for both sexes. Folic acid was inadequately consumed by males in both groups, significantly different from the female consumption, independent of the severity of the disease (tab. III).

\section{Discussion}

The results obtained in the present study show no significant difference between the groups studied in regard to the severity of coronary artery disease for the anthropometric, biochemical, and dietary parameters assessed, because of the stratification of the sample with a reduced number of individuals in each group. Relevant associations, however, occurred when males and females were compared.

In regard to the anthropometric study, some deviations compatible with an increased risk for coronary artery disease were observed. These deviations were mainly represented by thefollowing: bodymassindex $>25 \mathrm{~kg} / \mathrm{m}^{2}$; percent body fat greater than 24 and 30 in males and females, respectively; and the waist/hip ratio greater than 0.98 and 0.90 in males and females, respectively. Gaudet et $\mathrm{al}^{29}$ reported mean values of body mass index and waist/hip ratio in males with severe coronary artery disease of $28 \mathrm{~kg} / \mathrm{m}^{2}$ and 0.96 , respectively, compatiblewith the subsequent risk for acute ischemic events, such as acute myocardial infarction. Those authors concluded that body mass index, percent body fat, and waist/hip ratio were above the recommended values also in patients with cardiac disease confirmed on coronary arteriography.

Deprés and Lamarche ${ }^{30}$ related the accumulation of abdominal fat with dyslipidemia, and these individuals were more susceptible to an increase in triglycerides and a reduction in HDL-cholesterol. Korhonen et $\mathrm{al}^{31}$ observed significant differences in the lipid profile of patients with coronary artery disease with the degree of stenosis greater than $50 \%$, lower than $50 \%$, and individuals with no coronary artery disease, the profile of the first group having the greatest atherogenic potential. However, studies assessing the behavior of 2 or more risk indicators among individuals with coronary artery disease and coronary obstruction according to the severity of the lesion are still rare in the literature.

The biochemical analysis revealed a reduction in HDLcholesterol in males, an increase in LDL-cholesterol in males and females, and total serum cholesterol above the recommended levels in all groups, according to the $2^{\circ}$ Consenso Brasileiro de Dislipidemias ${ }^{32}$. Similar results were observed in individuals undergoing coronary angiography for assessing coronary lesions in vivo ${ }^{33}$ in a clinical assay carried out in postmenopausal females with coronary artery disease and previous acute myocardial infarction ${ }^{34}$, and in a study ${ }^{35}$ with

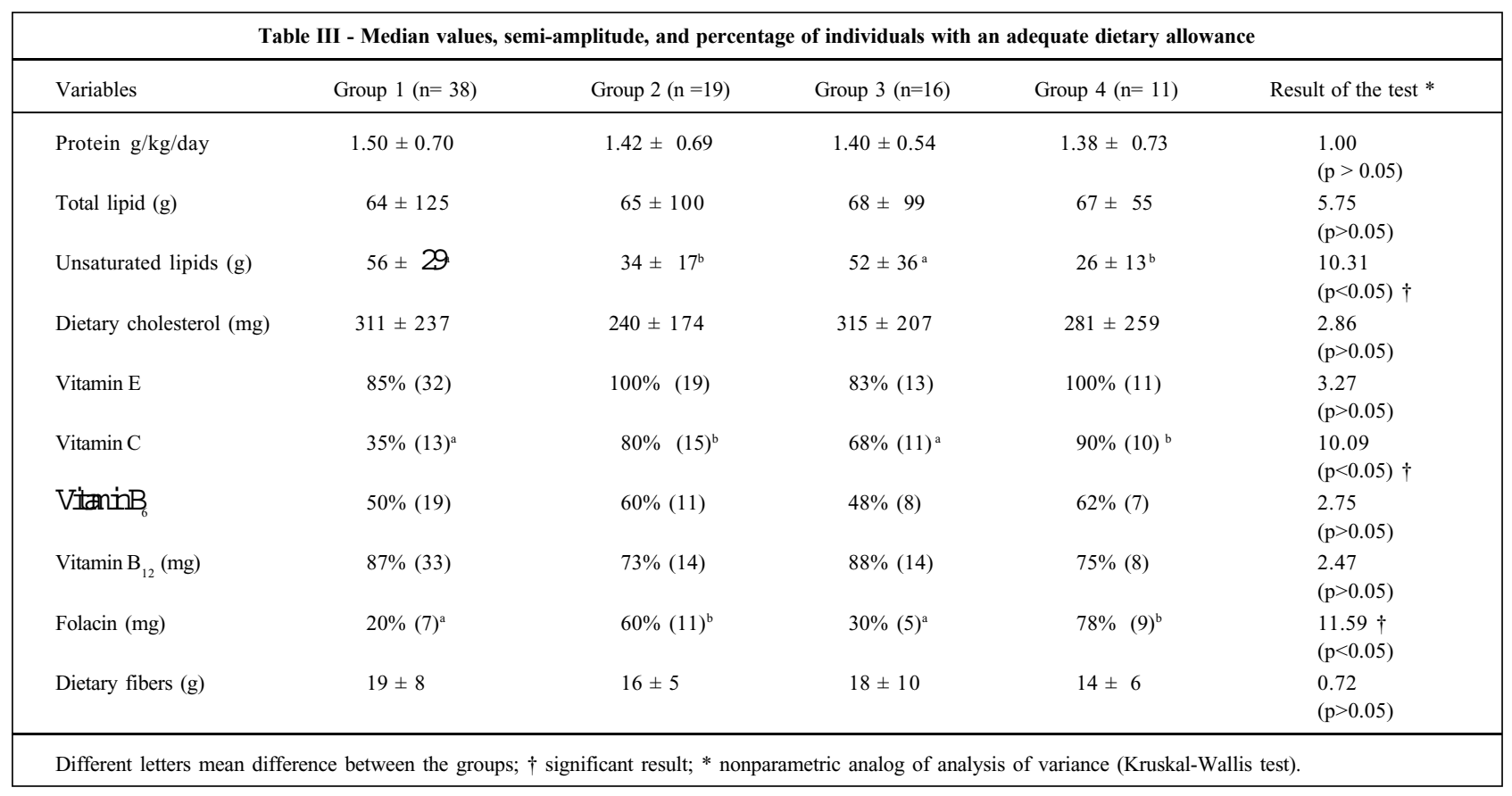


dyslipidemic males and females with coronary artery disease. Individuals with these patterns of serum lipids have a greater predisposition to recurring events, such as angina pectoris, acutemyocardial infarctionorsuddendeath, orboth ${ }^{36,37}$.

In the present study, the total cholesterol/HDL-c ratio was compatible with the risk for coronary artery disease ${ }^{38}$, mainly in males with severe lesions, and this was the only discriminating indicator of the severity of the lesion.

Hypertriglyceridemia and hyperglycemia were observed mainly in the females of both groups, independent of the extension of the coronary lesion. Hyperglycemia and diabetes mellitus are frequently observed in females. Pyorala et $\mathrm{al}^{39}$ related positively fasting glycemia and atherosclerotic complications in nondiabetic individuals. Glycemic control of individuals with coronary artery disease improves the prognosis of coronary artery disease and reduces mortality ${ }^{40,41}$. Hokanso and Austin ${ }^{42}$ observed that high triglyceride levels correspond to a $75 \%$ higher risk in females with cardiac disease. Elisaf et al ${ }^{43}$ found significant differences in the serum triglyceride levels of individuals with coronary artery lesions $\geq 70 \%$ and those of individuals with coronary artery lesions $<70 \%$, strengthening the concept that triglyceride levels increase according to the severity of the coronary artery disease both in males and females, unlike our results ${ }^{44}$.

Another biochemical parameter assessed that has been positively associated with the genesis of coronary artery disease is plasma homocysteine, considered by several authors an independent marker of early atherogenesis through still unclear mechanisms ${ }^{45,46}$. Even though plasma homocysteine has been exhaustively studied, mainly in the past few years, its normal reference values are still a matter of controversy. The variations may be attributed to methodological differences in homocysteine measurement, in the processing of the sample, and in the selection of the individuals, because factors, such as age, sex, and menopause may influence homocysteinemia ${ }^{47}$. In the present study, we used the values proposed by Ubbink et $\mathrm{al}^{6}$, who adopted a mathematical predictormodel to establish the normal range of fasting homocysteine, and we found that a significant percentage of males $(30 \%)$ had homocysteine levels above the recommended values.

Ueland et a ${ }^{47}$ adopted the cut point $\geq 8.56 \mu \mathrm{mol} / \mathrm{L}$ for moderate homocysteinemia. When this cut point was adopted in our study, the percentage of hyperhomocysteinemic males increased to $45 \%$. Bots et al ${ }^{48}$ and Nygard et al ${ }^{49}$ also reported increased plasma fasting homocysteine levels in males as compared with those of females, independent of the severity of the disease. The female homocysteine levels in our study were not comparable to those in the literature, because, according to Ridker et al ${ }^{50}$, menopausal females are normally hyperhomocysteinemic.

Another important point to be considered is the low sensitivity of the measurements of fasting homocysteinemia. Dogamala et al ${ }^{51}$ identified, after the overload test with methionine, hyperhomocysteinemia in 39\% of the patients who had normal or borderline basal levels.

Cunha ${ }^{52}$ reported that individuals with coronary artery disease and severe lesions had homocysteine levels above those found in the group with no coronary artery disease. Mayer et a ${ }^{53}$ reported a directly proportional association between the degree of coronary artery obstruction and homocysteine levels.

Even though extremely high median values have not been found, the importance of this alteration should not be disregarded, mainly because it refers to patients with established coronary artery disease, who have other risk factors, such as dyslipidemia, increased body fat, and inadequate dietary allowance.

According to Malinow et al ${ }^{54}$, the percentage of abnormally high homocysteine levels among individuals with coronary artery disease is approximately 20 to $30 \%$, which is identical to the percentage observed in the males of the present study.

Dietary composition has other implications in coronary artery disease, it being important to monitor some risk factors, such as dyslipidemia, obesity, and hyperhomocysteinemia. In our study, an excessive intake of total lipids and cholesterol and an inadequate intake of unsaturated lipids were observed in both sexes. In regard to caloric dietary distribution and macronutrients, we observed the ingestion of diets with a high percentage of proteins and lipids and a low percentage of carbohydrates. Watts et $\mathrm{al}^{55}$, analyzing the progression of coronary artery disease in the male sex, observed a significant association with the amount of total and unsaturated fat in the diet. The intake of a similar diet was observed by Knoop et a ${ }^{56}$ in individuals with coronary artery disease with a lipid intake of $36 \%$ in the diet and a mean dietary cholesterol consumption of $320 \mathrm{mg} /$ day. Singh et al ${ }^{64}$ observed the ingestion of high-fat and high-protein diets in their group of patients with coronary artery disease; however, the amount of dietary fiber intake of their patients was greater than that observed in the present study, in which that amount was extremely inadequate for both sexes.

The antioxidant components are significant dietary factors that prevailed in the diets of the females, of which a greater percentage showed adequate amounts of vitamin $\mathrm{C}$ and a-tocopherol according to the NRC/RDA ${ }^{21}$. These results were similar to those reported by Singh et al ${ }^{58}$ in hospitalized patients with previous acute myocardial infarction.

Rosegren et al ${ }^{59}$, studying patients who survived acute myocardial infarction, reported that the increased subsequent mortality risk was due to the maintenance of risk factors, such as smoking, dyslipidemia, and systemic arterial hypertension.

Our results showed that the individuals with coronary artery disease assessed in this study had alterations in risk factors, such as overweight, dyslipidemia, positive familial history for coronary artery disease, smoking, and inadequacy of dietary habits. These alterations were present in varied degrees according to sex and did no differ depending on the severity of the coronary artery lesion. Therefore, we observed the persistence of alterations in risk factors, even after the diagnosis of coronary artery disease, confirming the recurrence of ischemic events. This may have resulted from the lack of guidance and follow-up for correcting the risk factors that could be controlled. 


\section{References}

1. American Heart Association. Heart and stroke facts: 1995 statistical supplement. Dallas: AHA, 1994.

2. Hornstra G, Barth CA, Galli C, et al. Functional food science and the cardiovascular system. Br J Nutr 1998; 80(suppl 1): 113s-46s.

3. Danchin N, Vaur L, Genés N, et al. Management of acute myocardial infarction in intensive care units in 1995: a nationwide French survey of practice and early hospital results. J Am Coll Cardiol 1997; 30: 1598-605.

4. Wood D, Backer G, Faergeman O, Graham I, Mancia G, Pyörala K. Prevention of coronary disease in clinical practice: Recommendations of the second task force of European and other Societies on coronary prevention. Atherosclerosis 1998; 140: $199-270$.

5. Summary of the report of the national cholesterol education program (NCEP)Expert Panel on detection, evaluation and treatment of high blood cholesterol in adults (Adult Treatment panel II). JAMA 1996; 269: 3015-23.

6. Ubbink JB, Becker PJ, Vermaak H, Delport R. Results of B-vitamin supplementation study in a prediction model to define a reference range for plasma homocysteine. Clin Chem 1994; 41: 1033-7.

7. World Health Organization. Diet, nutrition and preventing of chronic diseases. Geneva: WHO, 1990 (Reports of WHO)

8. Sociedade de Cardiologia do Estado de São Paulo. Cardiologia/SOCESP. São Paulo: Atheneu, 1996.

9. Lohman TG, Roche AF, Martorell R. Anthropometrics standardization reference manual. Illinois: Human Kinetics Books, 1998.

10. Pollock ML, Willmore JH. Exercício na saúde e na doença: avaliação e prescrição para prevenção e reabilitação. $2^{\mathrm{a}} \mathrm{Ed}$. Rio de Janeiro: Medsi, 1993.

11. Frisancho AR. Anthropometrics standards for the assessment of growth and nutritional status. The University of Michigan Press, 1990.

12. Durnin JVGA, Womersley J. Body fat assessed from total body density and its estimation from skin fold thickness: measurements on 481 men and women aged from 16 to 72 years. Br J Nutr 1974; 77: 5-7.

13. World Health Organization. Obesity: preventing and managing the global epidemic. Geneva: WHO 1998 (Reports of WHO. Consultation on obesity).

14. Frisancho AR. Anthropometrics standards for the assessment of growth and nutritional status. The university of Michigan press, 1990.

15. Bray GA. Classificação e avaliação das obesidades. In: Obesidade: Conceitos Básicos e Aplicações Clínicas. Clin Med Am Norte 1989; 1: 189-216.

16. Katch FI, Katch VL. The body composition profile: techniques of measurement and applications. Clin Sports Med 1984; 3: 31 .

17. Inan - Brasil, Ministério da Saúde. Registro fotográfico para inquéritos dietéticos: utensílios e porções. Brasília, 1996.

18. Soares EA, Portela ESS, Ishi M. Relação de medidas caseiras de 320 alimentos e respectivas gramagens. São Paulo: Ceane, 1991.

19. Pinheiro ABV, Lacerda EAM, Benzecry EH, Gomes MCS, Costa VM. Tabela para avaliação de consumo alimentar em medidas caseiras. Rio de Janeiro (s.ed), 1996.

20. Philippi ST, Szarfarc SC, Latterza AR. Virtual Nutry - versão 1.0 for windows. São Paulo: Faculdade de Saúde Pública - USP, 1996.

21. National Research Council. Recommended dietary allowances. $10^{\text {th }}$ ed., Washington: National Academy of Science, 1989.

22. Ubbink JB, Vermaak WJH, Bissbort S. Rapid high-performance liquid chromatographic assay for total homocysteine levels in human serum. J Chromat 1991; 565: 441-6.

23. Friedwald WT, Levy RI, Fredrickson DS. Estimation of the concentration of lowdensity lipoprotein cholesterol in plasma, without use of the preparative ultracentrifuge. Clin Chem 1972; 18: 499-502.

24. Castelli WP, Garrison RJ, Wilson PW, Abbott RD, Kalousdian S, Kannel WB. Incidence of coronary heart disease and lipoprotein cholesterol levels. The Framingham Study. JAMA 1986; 256: 2835-8.

25. Consenso Brasileiro sobre Dislipidemias. Avaliação - Deteç̧ão - Tratamento. Arq Bras Cardiol 1996; 67: 109-22.

26. American Diabetes Association. Complete guide to diabetes. Alexandria: American Diabetes Association, 1997.

27. Siegel S. Nonparametric statistics for the behavioral sciences. New York: McGraw-Hill, 1965

28. World Health Organization. Obesity: preventing and managing the global epidemic. Geneva: WHO, 1998 (Reports of WHO. Consultation on obesity).

29. Gaudet D, Vohl MC, Perron P, et al. Relationship of abdominal obesity and hyperinsulinemia to angiographically assessed coronary artery disease in men with known mutations in the LDL receptor gene. Circulation 1998; 97: 871-7.

30. Deprés JP, Lamarche B. Effects of diet and physical activity on adiposity and body fat distribution: implications for the prevention of cardiovascular disease. Nutr Res Rev 1993; 6: 137-59.

31. Korhonen T, Savolainen MJ, Koistinem JM, et al. Association of lipoprotein cholesterol and tryglicerides with the severity of coronary artery disease in men and women. Atherosclerosis 1996; 127:213-20.
32. Consenso Brasileiro sobre Dislipidemias. Avaliação - Detecção - Tratamento. Arq Bras Cardiol 1996; 67: 109-22.

33. Kitamura K, Mizuno K, Miyamoto A, Nakamura H. Serum lipid and the presence of yellow plaque in coronary lesions in vivo. Am J Cardiol 1997; 79: 676-8.

34. Lewis SJ, Sacks FM, Mitchell JS, et al. Pravastatin effects on cardiovascular events in women after myocardial infarction: The Cholesterol Study. J Am Coll Cardiol 1999; 32: 140-6.

35. Andrews TC, Raby K, Barry J, et al. Effect of cholesterol reduction on myocardial ischemia in patients with coronary disease. Circulation 1997; 95: 324-8.

36. Rose G, Hamilton PJ, Keen H, Reid DD, MC Cartney P, Jarret RJ. Myocardial ischemia, risk factors and death from coronary heart disease. Lancet 1997; Volume??: 105-9

37. Andrews TC, Raby K, Barry J, et al. Effect of cholesterol reduction on myocardial ischemia in patients with coronary disease. Circulation 1997; 95: 324-8.

38. Castelli WP, Garrison RJ, Wilson PW, Abbott RD, Kalousdian S, Kannel WB. Incidence of coronary heart disease and lipoprotein cholesterol levels. The Framingham Study. JAMA 1986; 256: 2835-8

39. Pyorala K. Preventive Cardiology: a progress report. Prev Med 1990; 19: 78-96

40. Uusitupa MIJ, Niskanen LK, Siitonem O, Voutilainem E, Pyörala K. Ten-year cardiovascular mortality in relation to risk factors and abnormalities in lipoprotein composition in type 2 (non-insulin-dependent) diabetic and non-diabetic subjects. Diabetologia 1993; 36: 1175.

41. Anderson DKG. Diabetes mellitus in a defined population. A longitudinal study with special reference to early diagnosis, occurrence and mortality. Comprehensive summaries of Upscale dissertations from the Faculty of Medicine. Stockholm: Almqvist and Wiksell International, 1994.

42. Hokanso JE, Austin MA. Plasma triglyceride level is a risk factor for cardiovascular disease independent of high-density lipoprotein cholesterol level: a meta-analysis of population-based prospective studies. J Cardiovasc Risk 1996; 3: 213-9.

43. Elisaf MS, Siamopoulos KC, Tselegarides TL, et al. Lipid abnormalities in Greek patients with coronary artery disease. Intern J Cardiol 1997; 59: 177-84.

44. Korhonen T, Savolainen MJ, Koistinem JM, et al. Association of lipoprotein cholesterol and tryglicerides with the severity of coronary artery disease in men and women. Atherosclerosis 1996; 127: 213-20.

45. StampferMJ,Malinow MR, WilletMWC. A prospective study of plasma homocysteine and risk of myocardial infarction in US physicians. JAMA 1992; 268: 877-81.

46. Kang SS, Wong PKW, Malinow MR. Hyperhomocist(e)inemia as a risk factor for occlusive vascular disease. Annu Rev Nutr 1992; 2: 279-98.

47. Ueland PM, Refsum H, Stabler SP, Malinow RM, Anderson A, Allen RH. Total homocysteine in plasma or serum: methods and clinical applications. Clin Chem 1993; 39: 1764-79

48. Bots ML, Launer LJ, Lindemans J, et al. Homocysteine and short-term risk of myocardial infarction and stroke in the elderly. Arch Intern Med 1999; 159: 38-44.

49. Nygard O, Refsum H, Ueland PM, Vollset SE. Major lifestyle determinants of plasma total homocysteine distribution: the Hordaland Homocysteine Study. Am J Clin Nutr 1998, 67: 263-70.

50. Ridker PM, Manson JE, Buring JE, Matias M, Hennekens CH. Homocysteine and risk of cardiovascular disease among postmenopausal women. JAMA 1999; 281: $1817-21$.

51. Dogamala TB, Libura M, Szczeklik A. Hyperhomocisteinemia following oral methionine load is associated with increased lipid peroxidation. Thromb Res 1997; 8794: 411-6.

52. Cunha CLP. Homocisteína e doença arterial coronariana - estudo em 195 pacientes submetidos a cineangiocoronariografia (Dissertação). Curitiba: Universidade Federal do Paraná, 1997.

53. Mayer EL, Jacobsen DW, Robinson K. Homocysteine and coronary atherosclerosis. J Am Coll Cardiol 1995; 27: 517-27.

54. Malinow MR, Kang SS, Taylor LM, et al. Prevalence of hyperhomocist(e)inemia in patients with peripheral arterial occlusive disease. Circulation 1989; 79: 1180-8.

55. Watts GF, et al. Nutrient intake and progression of coronary artery disease. Am J Cardiol 1994; 73: 328-32.

56. Knoop RH, Walden CE, Retzlaff BM, et al. Long-term cholesterol-lowering effects of 4 fat-restricted diets in hypercholesterolemic and combined hyperlipidemic men. The Dietary Alternatives Study. JAMA 1997; 278: 1509-15.

57. Singh RB, Rastogi SS, Verma R, et al. Randomized controlled trial of cardioprotective diet in patients with recent acute myocardial infarction: results of one year follow up. Br Med J 1992; 304: 1015-9

58. Singh RB, Niaz MA, Agarwal P, Begom R, Rastogi SS. Effect of antioxidant-rich foods on plasma ascorbic acid, cardiac enzyme, and lipid peroxide levels in patients hospitalized with acute myocardial infarction. J Am Diet Assoc 1995; 95: 775-80.

59. Rosegren A, Wilhelmsen L, Hagman M, Wedel H. Natural history of myocardial infarction and angina pectoris in a general population sample of middle-aged men: a 16-year follow-up of the Primary Prevention Study, Göterborg, Sweden. J Intern Med 1998; 244: 495-505. 